\title{
Совершенствование технологии возделывания картофеля в системе точного земледелия
}

\section{А.И. Беленков, Е.В. Березовский, С.В. Железова}

Приведены сведения о внедрении и освоении технологи точного земледелия на примере картофеля в полевом опыте Центра точного земледелия РГАУ - МСХА имени К.А. Тимирязева. Установлено, что при сравнении с традиционной технологией, с помощью точной лучше и качественнее проводить посадку картофеля и гребнеобразование по всходам с использованием спутникового навигационного оборудования системы GPS. Преимущество точной технологии проявилось в получении более высокой урожайности, которая превышала традиционную технологию, в среднем за годы исследований, на 0,8 т/га, при этом отвальная обработка опережала минимальную по точной технологии на 2,3 т/га, по традиционной - на 3.4 т/га.

Ключевые слова: точное (координатное) земледелие, картофель, технология возделывания, прием обработки почвы, автопилот, маркер, стыковые междурядья, гребнеобразование, полезная площадь, урожайность.

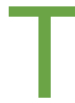

очное (координатное) земледелие в последние два десятилетия прочно вошло в теорию и практику с.- х. производства, как в передовых странах мира, так и в нашей стране [1, 2].

В 2007 году в составе Полевой опытной станции РГАУ - МСХА имени К.А. Тимирязева был создан научный Центр точного земледелия (ЦТЗ). В задачу Центра, помимо обучения студентов и проведения повышения квалификации научных работников, входило внедрение на основе полевого опыта и освоение отдельных базовых звеньев точного (координатного) земледелия. К числу таковых относятся посев (посадка) с.- х. культур с использованием оборудования космического автопилотирования системы GPS, дифференцированное внесение удобрений и средств химической защиты растений, применение сенсоров и датчиков в ходе проведения различных агротехнических операций при возделывании полевых культур [3].

Цель наших исследований - на примере полевого опыта ЦТЗ продемонстрировать эффективность и результативность внедрения и освоения точного земледелия при возделывании ведущих зерновых и пропашных культур Центрального Нечерноземья [4].

Исследования проводили в 2010-2016 годах полевом зернопропашном севообороте с чере- дованием культур: викоовсяная смесь на корм - озимая пшеница с пожнивным посевом горчицы на сидерат - картофель - ячмень.

В рамках полевого эксперимента на картофеле изучали два фактора: А - технология возделывания (точная и традиционная) и В - приемы обработки почвы (отвальная и минимальная). Точная технология включала использование средств спутниковой навигации при посадке и гребнеобразовании. Традиционная предполагала выполнение указанных агроприемов в ходе ручного управления агрегатом.

Для обработки почвы в первом случае использовали отвальный оборотный плуг, во втором - мульчиров- щик для мелкой заделки сидерата. Перед проведением обработок пожнивная горчица скашивалась и измельчалась, а затем заделывалась в почву. Весенняя обработка состояла из покровного боронования зяби и предпосадочной обработки вертикальной фрезой. Посадку предварительно протравленных клубней картофеля проводили на всех вариантах импортной картофелесажалкой GL-34T с одновременным внесением гербицида и фунгицида [5]. По традиционной технологии агрегатом управлял механизатор с использованием маркера, на делянках точного земледелия посадку проводили по автопилоту [6] (рис. 1).

Точно также в ходе гребнеобразования, после появления всходов, при традиционном возделывании культуры агрегат по обозначившимся рядкам вел непосредственно механизатор. По точной технологии движение гребнеобразователя копировал автопилот по заданной изначально в ходе посадки траектории (рис. 2).

Период проведения эксперимента сопровождался неодинаковыми метеоусловиями, когда наблюдалось чередование относительно влажных, умеренных и засушливых лет. Так, 2010 год можно охарактеризовать как засушливый, 2011, 2012

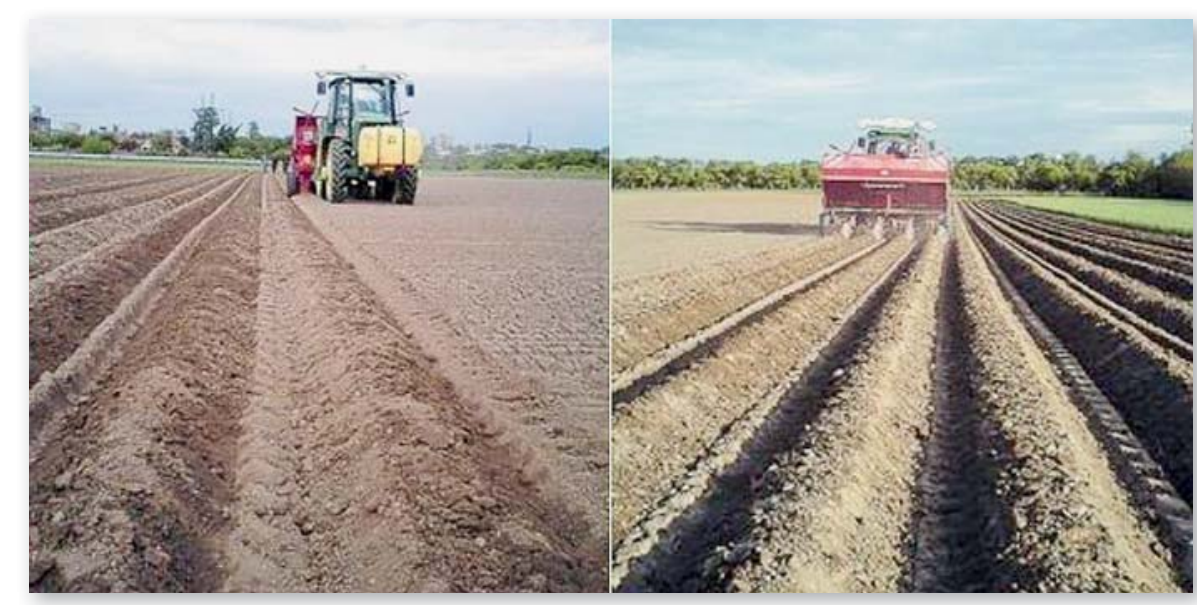

Рис. 1. Посадка картофеля с использованием системы «Автопилот» 


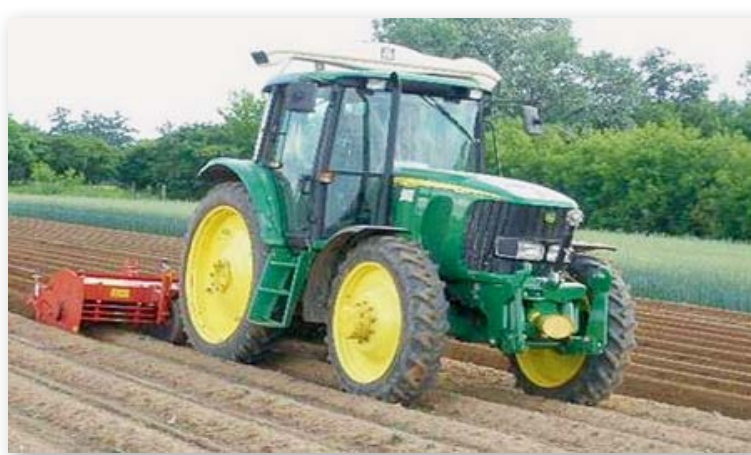

Рис. 2. Гребнеобразование картофеля с использованием системы «Автопилот»

и 2014 годы - умеренные по увлажнению, 2013, 2015 и 2016 годы - достаточно влажные. Такое распределение лет по метеоусловиям сказалось на продуктивности картофеля.

В разные годы высаживали различные сорта картофеля, в силу вырождения и сильного снижения урожайности, к примеру, в 2012 году.

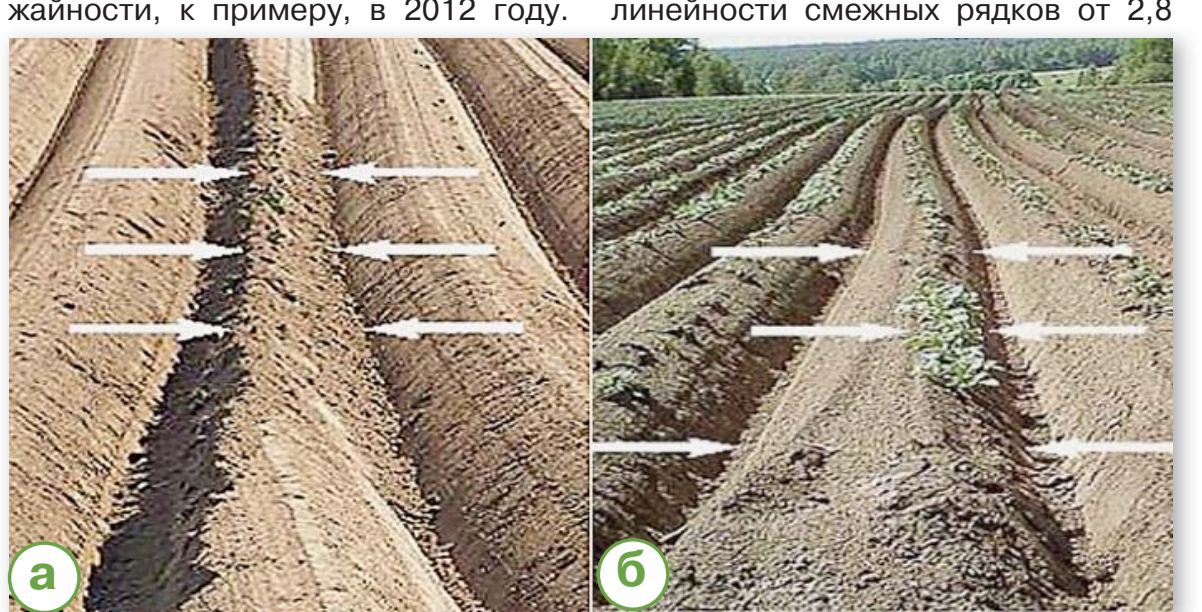

Рис. 3. Возможные проблемы при гребнеобразовании картофеля (работа без автопилота): а- сужение гребня; б- отклонение от центра

В разные годы в опытах выращивали сорта Удача, Жуковский ранний, Невский, Снегирь, Рябинушка, Аврора, Голубизна.

Посадку картофеля проводили картофелесажалкой GL-34T по автопилоту и по маркеру (рис. 2). Заданная траектория движения аг-

регата, с использованием системы GPS, повторялась на варианте точного земледелия в ходе проведения гребнеобразования по всходам картофеля. По традиционной технологии возделывания картофеля этот прием проводился визуально, т.е. движением агрегата управлял механизатор. Ширина междурядий между проходами картофелесажалки при использовании маркера и автопилота отличалась по отдельным годам незначительно, составляя по традиционной технологии интервал в среднем от 60-65 до 8085 см, т.е. отклонение от стандартного междурядья сажалки (75 см) находилась в пределах от -15 до +10 см. Применение системы «Автопилот» обеспечивало отклонение от прямолинейности смежных рядков от 2,8

до 3,0 см [7].

Важное условие развития полноценного растения картофеля - его расположение по отношению к центральной части гребня, формируемое в ходе проведения гребнеобразования после появления всходов. Гребнеобразование в посадках кар-

Таблица 1. Частота встречаемости (\%) отклонений растений картофеля от центра гребня в опыте РГАУ - МСХА имени К.А. Тимирязева, 2010-2016 годы

\begin{tabular}{|l|c|c|c|c|}
\hline \multirow{2}{*}{ Отклонение, см } & \multicolumn{3}{|c|}{ По маркеру } & \multicolumn{2}{c|}{ GPS } \\
\cline { 2 - 5 } & минимальная & отвальная & минимальная & отвальная \\
\hline $0-2$ & 14 & 17 & 40 & 41 \\
\hline $3-5$ & 35 & 20 & 48 & 37 \\
\hline $6-8$ & 25 & 24 & 10 & 15 \\
\hline $9-11$ & 17 & 25 & 2 & 6 \\
\hline $12-14$ & 7 & 14 & - & 1 \\
\hline$>14$ & 2 & - & - & - \\
\hline
\end{tabular}

тофеля, возделываемых по традиционной технологии, обеспечивало формирование растений картофеля с отклонениями от центра от 10 до 15 см (рис. 3 а,б). Это приводило к одностороннему изменению нарастания вегетативной части, неравномерности в образовании и развитии подземных клубней, а главное к снижению качества продукции изза появления большого количества зеленого картофеля.

При применении технологии точного земледелия растения картофеля располагались по центру рядка с отклонением от 2,8 до 3,5 см. Сочетание двух проходов агрегата по полю, а именно, посадки и гребнеобразования картофеля представлены в табл. 1.

Проведение обработок с применением автопилота на основе системы GPS, с корректировкой сигнала в режиме реального времени, показывает высокую точность. Так, на вспашке критические отклонения (рис. 4) свыше 8 см составили $7 \%$ случаев, на минимальной обработке - 2\%. При посадке по маркеру и глазомерном гребнеобразовании критические отклонения встречаются чаще, соответственно в 39 и $26 \%$ случаев (рис. 4).

Таким образом, при работе с пропашными культурами к системе GPS (ГЛОНАСС) и техническим средствам автоматического ведения МТА предъявляются следующие требования: ведение агрегатов в реальных полевых условиях из-за наложения одного прохода на другой должно достигать точности в отклонениях каждого прохода не более \pm 4 см по рабочим органам в 95\% случаев [8].

Необходимо отметить, что кроме высокоточной системы обработки спутниковых навигационных сигналов необходима соответствующая автоматическая система управления трактором. Скажем, компания John Deere уже на заводах устанавливает на свои тракторы системы типа «Автопилот». Есть и другие системы подруливания, реагирующие на соответствующие навигационные сигналы. Можно установить сервопривод на рулевое управление трактора, который тоже будет автоматически управлять движением машины. Тенденция на сегодняшний день такова, что без сомнения, за системами параллельного вождения и автопилотами, будущее современного с. - х. производства (рис. 5).

В полевом опыте ЦТЗ сравнивались величины отклонений ряд- 


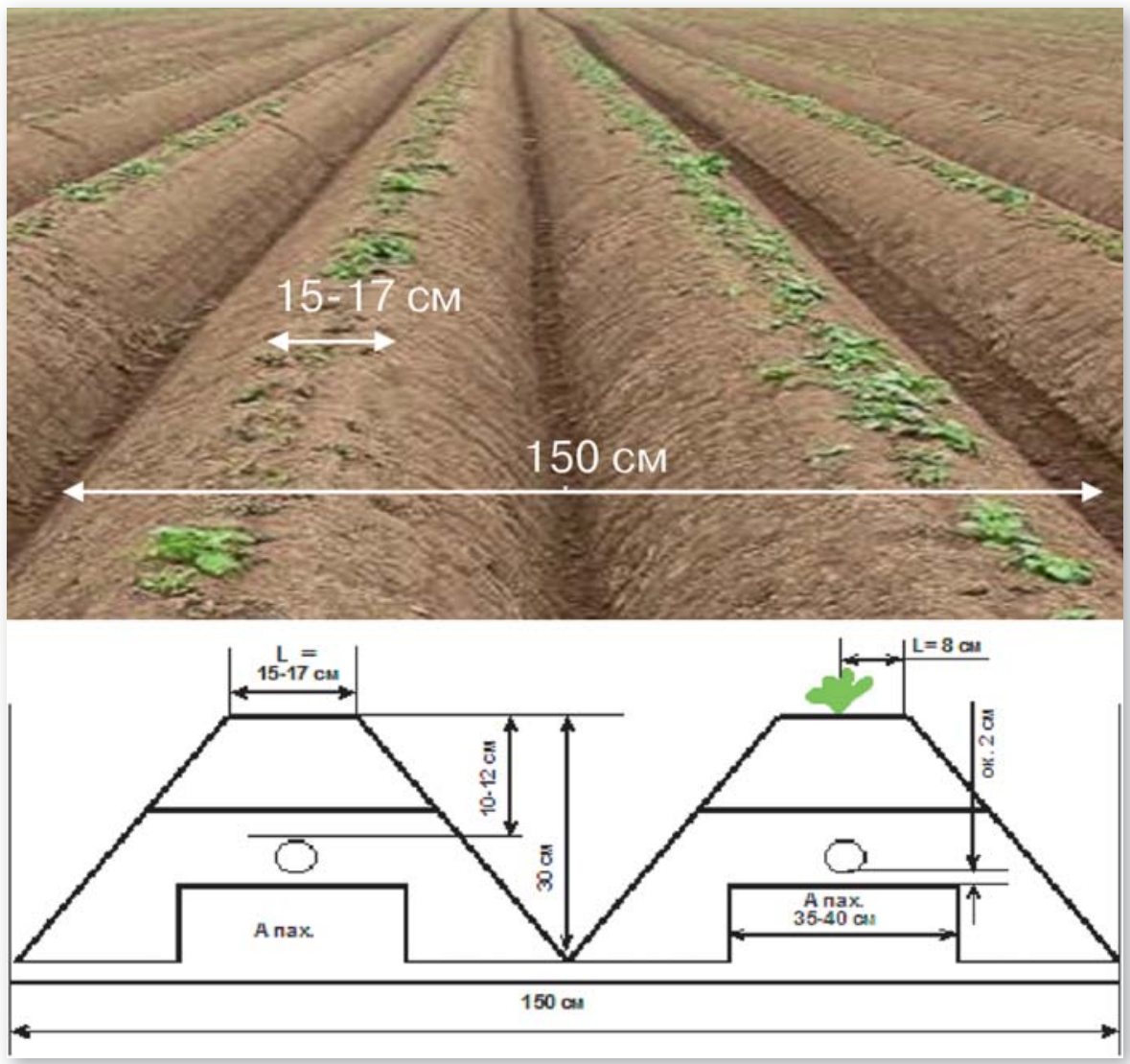

Рис. 4. Иллюстрация и схема гребнеобразования в посадках картофеля: $L$ - расстояние от растения до центра гребня

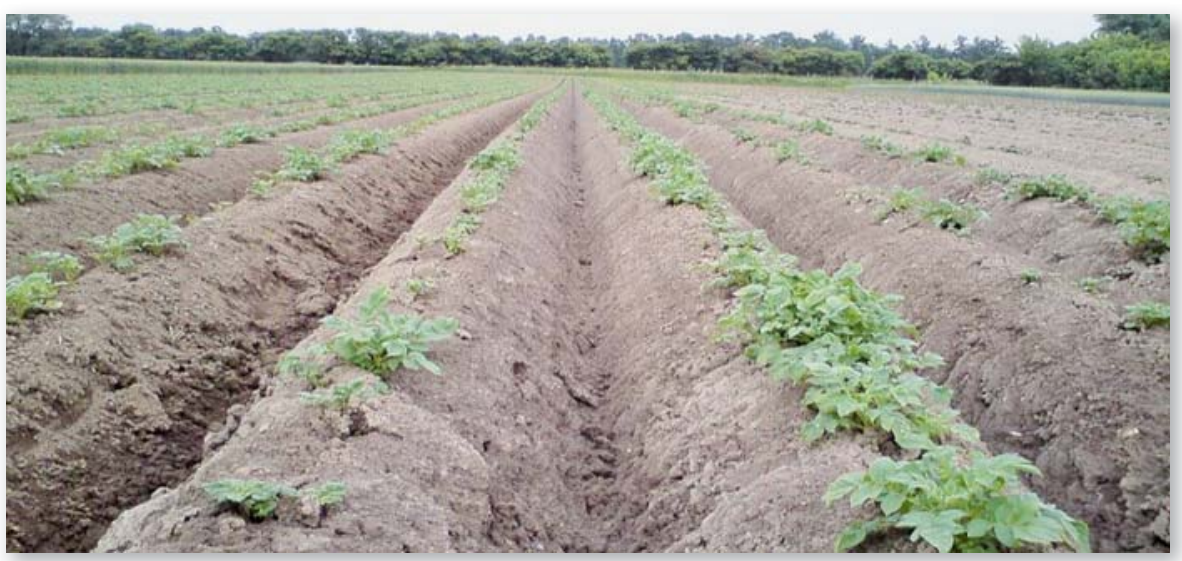

Рис. 5. Идеально прямолинейные гребни и всходы картофеля (посадка и гребнеобразование проводились по автопилоту)

ков растений от центра гребня при разных технологиях возделывания. На основе анализа данных среднего значения отклонений можно сделать вывод о том, что способ движения машинно-тракторных агрегатов по автопилоту более выровнен по траектории в условиях как минимально обработанной почвы, так и отвальнообработанной. Во втором случае отклонения были минимальны.
Таким образом, способ движения сельхозтехники по автопилоту показал себя достаточно неплохо, как в условиях минимальной, так и в условиях классической (отвальной) обработок почв, способ же движения по маркеру показал худший результат в тех же условиях. Возможное объяснение этому явлению заключается в том, что механизатору для изменения курса движения при отклонении от заданной траектории необходи- мо визуально обнаружить это самое отклонение, то есть оно должно быть достаточно большим для того, чтобы его можно было заметить. Автопилот же, используя точные данные о своем местоположении способен реагировать на незначительные отклонения, которые могут быть незаметны при визуальной оценке. Отклонения от заданной траектории движения трактора приводят к неэффективному использованию полезной площади поля (пропуски, перекрытия).

Увеличение стыковых междурядий влечет увеличение свободных площадей между проходами, которые потенциально можно занять картофелем. Обработка почвы по автопилоту показала высокую точность как на варианте с минимальной обработкой, так и на варианте с классической. Обработка по маркеру показала одинаково худший результат на обоих вариантах обработки почв, что в результате приводит к потере почти 1 га из 100.

Помимо снижения эффективности использования полезной площади полей, отклонения при проходе агрегатов приводят к смещению рядков относительно гребней, что может существенно снижать урожайность и товарность картофеля.

В Полевом опыте ЦТЗ получены результаты, на основании которых можно сделать предварительные выводы о влиянии обработки почвы и возможных отклонений на урожайность (рис. 6) и фракционный состав картофеля.

Изучение фракционного состава проводилось на делянках, заложенных в разных местах поля, как на варианте вспашки, так и на варианте минимальной обработки. Места закладки опытных делянок выбирались с учетом величины отклонений от центра гребня так, чтобы были представлены все группы отклонений (в трехкратной повторности). Данные по фракционному анализу для минимальной обработки представлены на рис. 7.

Аналогичные исследования были проведены также на варианте с классической обработки почвы, результаты представлены на рис. 8. По этим данным можно сделать вывод о том, что при использовании автопилота, как на варианте с минимальной обработкой почвы, так и на варианте с классической обработкой, мы можем получить увеличение общей урожайности.

В целом, снижение урожайности картофеля при увеличении вели- 


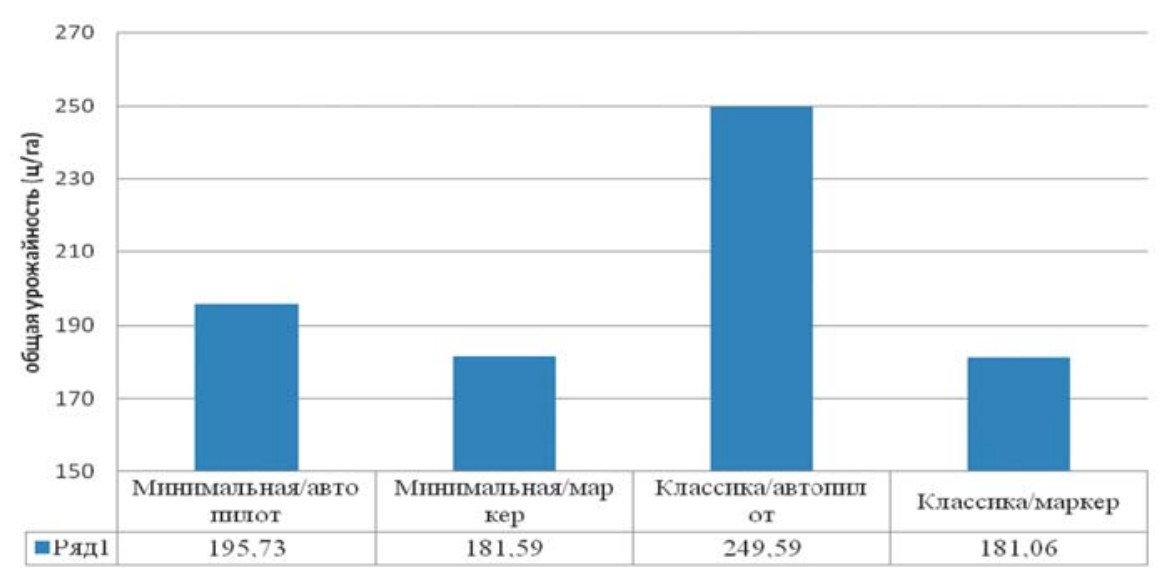

Рис. 6. Сравнение общей урожайности картофеля (ц/га) на разных вариантах опыт (в среднем за период исследований)

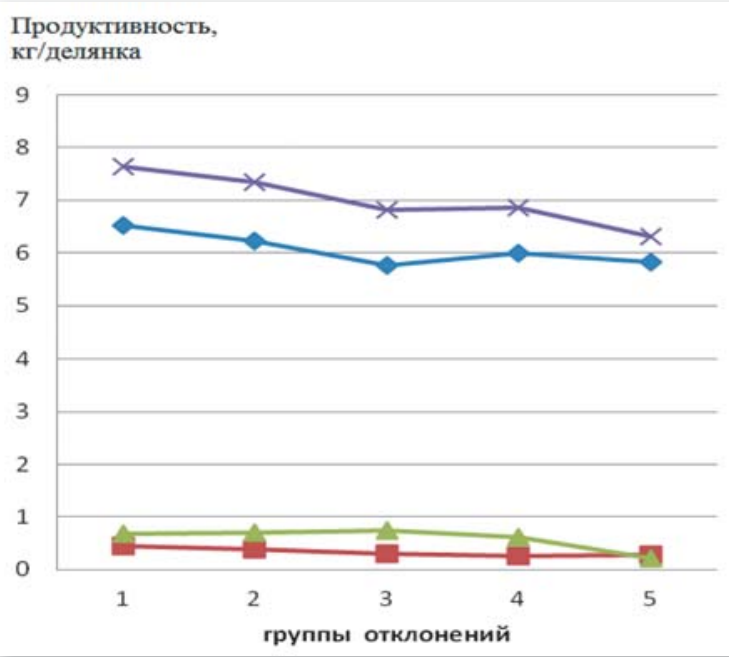

$\multimap$ —еменная фракщия, 30 $-60 \mathrm{MM},(\mathrm{KT})$

- - Фуражная фракция, $<30 \mathrm{MM}$, (KT)

- Продовольственная фракция, > $60 \mathrm{MM}$, (кт) $\longrightarrow$ Общая урожайность

Рис. 7. Фракционный состав и общая продуктивность картофеля на варианте с мини мальной обработкой почвы при разной степени отклонений рядка от центра гребня

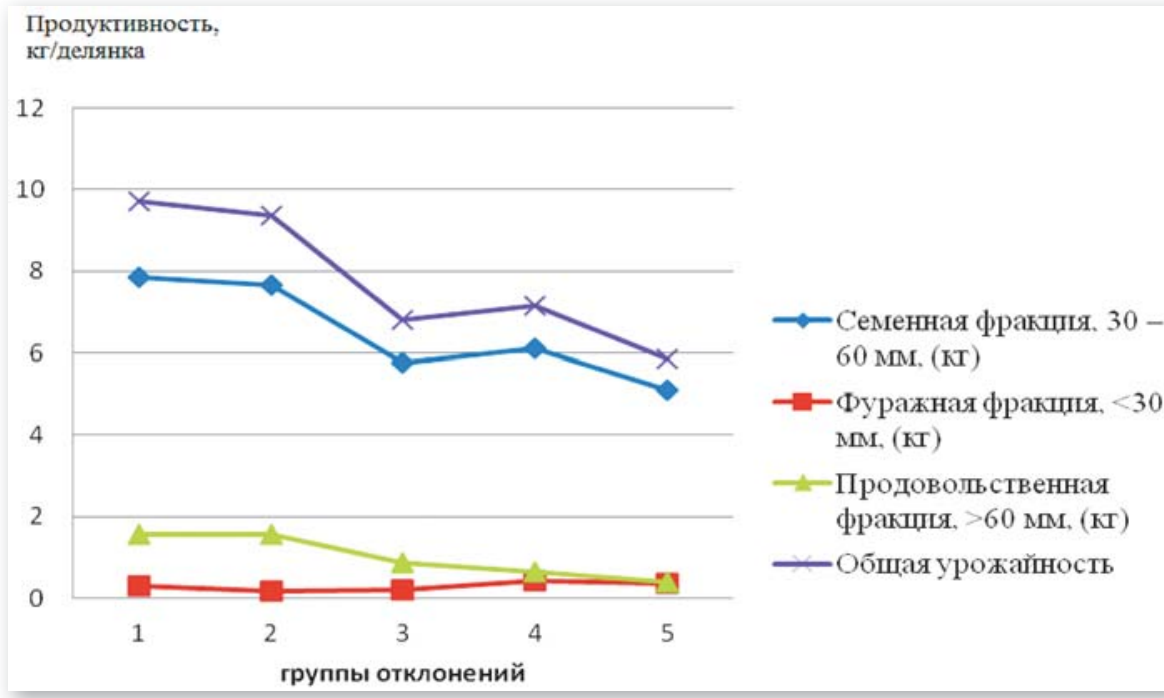

Рис. 8. Фракционный состав и общая продуктивность картофеля на варианте с отвальной (классической) обработкой почвы при разной степени отклонений рядка от центра гребня чины отклонений хорошо описывается линейным уравнением (рис. 9). Достоверность аппроксимации линейным уравнением очень высокая (коэффициент детерминации R2= 0,87).

Однако при логическом анализе зависимости, представленной на рис. 9, выделяется две области точек. Первая область точек относится к небольшим отклонениям (2-6\%), в этой области урожайность практически не отличается от мест с нулевым отклонением рядков от центра гребня. При увеличении размера отклонений на 10-15\% урожайность падает на 30\%. При еще большем отклонении (до 20\%) урожайность снижается на $40 \%$.

На вариантах с применением автопилота критические, т.е. существенно снижающие урожайность, отклонения от центра рядка встречаются не чаще чем в 9\% случаев, тогда как при применении маркера критические отклонения наблюдаются гораздо чаще, до $40 \%$ случаев. Следовательно, только за счет использования системы «Автопилот» можно повысить урожайность картофеля на 30\% при гарантированно высоком качестве продукции.

Результирующий показатель всякого агрономического исследования - продуктивность (урожайность) культуры (табл. 2).

Таким образом, технология точного земледелия имела относительное преимущество по сравнению с традиционной. При классической (отвальной) обработке разница в пользу первого варианта технологии возделывания составила 0,8 т/га, при минимальной - 1,1 т/га. По большинству лет эти различия статистически доказаны [9].

Наиболее наглядно представляются различия по урожайности картофеля при сравнении двух обработок почвы. В среднем на точной технологии разница составила 2,3 т/га, на традиционной - 2,6 т/га. По отдельным годам эти различия существенны и, в зависимости от агрометеорологических условий, характеристики сорта и уровня почвенного плодородия, находились в достаточно широком интервале варьирования. Тем ни менее приоритет отвальной обработки в сравнении с минимальной однозначен и доказан [10].

Выводы. При внедрении и освоении точного земледелия в рамках полевого опыта ЦТЗ следует использовать при посадке и в ходе гребнеобразования картофеля автопилот, 
Таблица 2. Урожайность картофеля по вариантам полевого опыта ЦтЗ в 2010-2016 годах, т/га

\begin{tabular}{|c|c|c|c|c|c|c|c|c|c|}
\hline \multirow{2}{*}{$\begin{array}{c}\text { Технология возделывания } \\
\text { (фактор А) }\end{array}$} & \multirow{2}{*}{$\begin{array}{c}\text { Обработка почвы } \\
\text { (фактор В) }\end{array}$} & \multicolumn{7}{|c|}{ Урожайность по годам, т/га } & \multirow{2}{*}{$\begin{array}{c}\text { Средняя } \\
\text { урожайность, т/га }\end{array}$} \\
\hline & & 2010 & 2011 & 2012 & 2013 & 2014 & 2015 & 2016 & \\
\hline \multirow{2}{*}{ точная } & отвальная & 21,7 & 24,4 & 19,9 & 28,6 & 25,1 & 32,9 & 31,0 & 26,2 \\
\hline & минимальная & 20,7 & 23,2 & 18,3 & 25,9 & 24,6 & 27,8 & 26,7 & 23,9 \\
\hline \multirow{2}{*}{ традиционная } & отвальная & 21,2 & 24,0 & 19,1 & 27,6 & 24.9 & 30,0 & 30,3 & 25,4 \\
\hline & минимальная & 19,2 & 22,9 & 17,5 & 26.2 & 23,8 & 24,6 & 25,6 & 22,8 \\
\hline \multirow{2}{*}{$\mathrm{HCP}_{05}, \mathrm{~T} / г \mathrm{a}$} & по фактору А & 0,33 & 0,25 & 0,42 & 0,39 & 0,46 & 0,75 & 1,14 & - \\
\hline & по фактору В & 0,42 & 0,50 & 0,56 & 0,26 & 0,90 & 1,08 & 2,11 & - \\
\hline
\end{tabular}

обеспечивающий качественное выполнение механизированных работ. Это не только позволяет увеличить полезную площадь поля в ходе применения элементов точного земледелия, но также способствует повышению урожайности культуры, предотвращает формирования мелкой и зеленой фракции. Таким образом, при проведении полевых работ следует ориентироваться на выполнение новых, прогрессивных технологий к числу которых, несомненно, относится точное (координатное) земледелие.

\section{Библиографический список}

1.Точное сельское хозяйство (precision agriculture) / Под ред. Д. Шпаара, А.В. Захаренко, В.П. Якушева СПб.: Пушкин, 2009. 400 с.

2.Программирование урожайности сельскохозяйственных культур при возделывании их с применением инновационных технологий / Под ред. А.С Овчинникова, И.Б. Борисенко, Ю.Н, Плескачева. Волгоград: Изд-во Волгоградской ГСХА, 2011. 145 с.

З.Якушев В.В., Воропаев В.В., Лекомцев п.В. Технология точного земледелия: опыт внедрения на полях Меньковской опытной станции АФИ РАСХН // Ресурсосберегающее земледелие. 2009. № 2. С. 31-34. 4.Балабанов В.И. и др. Навигационные технологии в сельском хозяйстве. Координатное земледелие: учебное пособие. М.: Изд-во РГАУ - МСХА им. К.А. Тимирязева, 2013. 148 с.
5.Плескачев Ю.Н., Роменская О.Н. Влияние микробиологических удобрений азотовит и фосфатовит на продуктивность картофеля в Нижнем Поволжье // Аграрный научный журнал. Саратов. 2018. № 1. С. 24-26

6.Элементы технологии точного земледелия в полевом опыте РГАУ - МСХА имени К.А. Тимирязева / А.И. Беленков, С.В. Железова, Е.В. Березовский, М.А. Мазиров // Известия ТСХА. 2011. Вып. 6. С. 90-100.

7.Belenkov A., Mazirov M., Arefieva V. Theoretical and practical aspects of basic soil treatment in the conditions of modern soil management systems in Russia // Eurasian Journal of Soil Science. 2018. № 7 (4). P. 300-307.

8.Беленков А.И., Сабо Умар, Кунафин Р.И. Основная обработка почвы: сравнительная оценка в современных системах земледелия // Нивы России. 2016. № 11 (144). С. 68-69.

9.Николаев В.А., Беленков А.И. Как обработка почвы влияет на ее агрофизику? // Фермер Поволжья. 2016. № 7. С. 32-35.

10.Беленков А.И., Сабо Умар, Малахов Н.В. Изучение влияния технологии обработки на плодородие дерново-подзолистой почвы в полевом опыте ЦТЗ // Агрохимический вестник. 2016. № 3. С. 29-32.

\section{Об авторах}

Беленков Алексей Иванович (Ответственный за переписку), доктор

с. - х. наук, профессор кафедры земледелия и МОД, ФГБОУ ВО РГАУ -

МСХА имени К.А. Тимирязева.

E-mail: belenokaleksis@mail.ru

Березовский Егор Валерьевич, канд. с. - х. наук, руководитель на- правления «Точное земледелие», ООО «Амазоне»

Железова Софья Владиславовна, канд. биол. наук, доцент кафедры земледелия и МОД, ФГБОУ ВО РГАУ -

МСХА имени К.А. Тимирязева.

Improvement of potato cultivation technology in the precision farming system

A.I. Belenkov (author for correspondence), DSc, professor of the Department of

Agriculture and MOU, RSAU - MAA named after K.A. Timiryazev.

E-mail: belenokaleksis@mail.ru

E.V. Berezovsky, PhD, Head of Precision

Farming, LLC Amazone

S.V. Zhelezova, PhD, Associate Professor of the Department of Agriculture and MOD, RSAU - MAA named after K.A. Timiryazev

Summary. Information on the introduction and development of technology of precision farming on the example of potatoes in the field experience of the Center of Precision Agriculture of the RSAU - MTAA named after K.A. Timiryazev is given. It has been established that, when compared with the traditional technology, potatoes were planted and combed on shoots using GPS satellite$$
y=-2,55 x+107,28
$$$$
R^{2}=0,87
$$

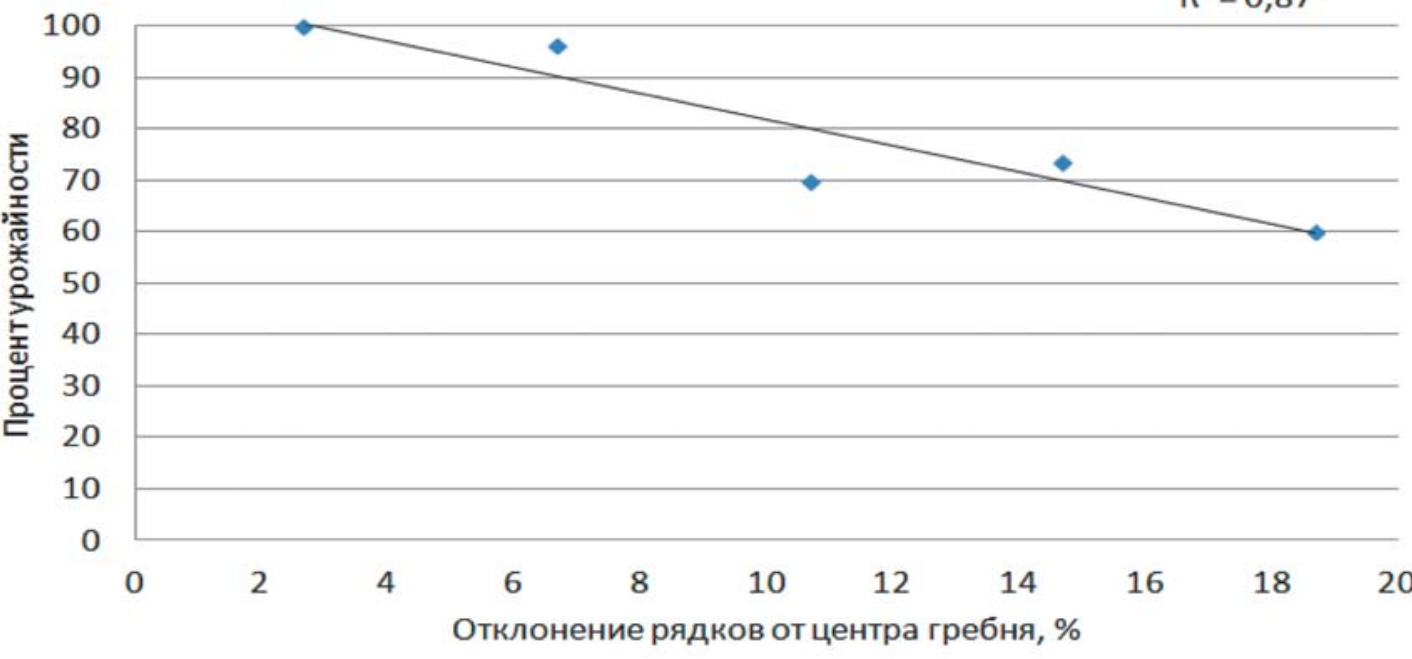

Рис. 9. Снижение урожайности картофеля (в \%) при повышении значений отклонения рядка от центра гребня navigation equipment, accurate, better and more qualitatively. The advantage of the exact technology manifested itself in obtaining higher yields, which exceeded the traditional technology, on average over the years of research, by $0.8 \mathrm{t} / \mathrm{ha}$, while the dump processing was ahead of the minimum by exact technology by $2.3 \mathrm{t}$ / ha, and by the traditional 3.4 t/ha.

Keywords: exact (coordinate) farming, potatoes, cultivation technology, tillage reception, autopilot, marker, aisles, ridge formation, effective area, yield. 